\title{
VALERIJS BITENIEKS - FROM A STUDENT OF RIGA POLYTECHNIC INSTITUTE TO A CONSTRUCTION CONTRACTOR IN THE INDEPENDENT LATVIA
}

\author{
ËRIKA LANKA* \\ University of Latvia
}

Summary. A paper on Valerijs Bitenieks, a graduate (1986) of the Faculty of Architecture and Civil Engineering of Riga Polytechnic Institute (RPI), reflects on the daily life of the Soviet students in the 1980s, the work of a young engineer while he was trying various opportunities in the labour market and the engineer's growth as a successful contractor in the independent Latvia in the 21st century. It traces the life of $V$. Bitenieks from his childhood to the present day, paying attention to his professional activities. The research provides an insight into students' internships and extracurricular activities during the Soviet era. Unpublished photographic material unknown to the general public has been obtained.

Keywords: Valerijs Bitenieks, Riga Polytechnic Institute, construction entrepreneurship.

\section{Introduction}

Valerijs Bitenieks, a graduate (1986) of the RPI Faculty of Architecture and Civil Engineering, engineer and construction contractor, was chosen as the focus of the present research as one of the many students of the 1980s to describe how new specialists studied and trained during the Soviet era, how the study process took place, how specialists were allotted to their future places of employment, and how the career of graduate engineers was developed. $V$. Bitenieks studied at one of the largest universities in Latvia - RPI, and his name is inextricably linked

\footnotetext{
* Corresponding author.
}

E-mail: erika.lanka@lu.lv 
with the life of RPI and events that happened in Latvia in the second half of the 20th century and in the 21st century. He has had to face drastic twists in his professional career, always finding a solution even in the most difficult situations. V. Bitenieks is a patriot of his own Alma Mater - RPI, currently Riga Technical University, the profession of a civil engineer and Latvia. Many photographs and documents provide documentary evidence on his life and work; some of them were used in the paper with the permission of $V$. Bitenieks. The current research was performed analysing documents, articles, and photo archives, and personally interviewing $V$. Bitenieks. The aim of the paper is to reflect on the everyday life of the Soviet students in the 1980s and the achievements of the engineer $V$. Bitenieks in his professional career at the end of the 20th century and in the first 20 years of the 21st century.

\section{Bitenieks' Family, Childhood, School and First Steps in his Professional Activity}

Valerijs Bitenieks was born on 14 January 1960 in Yakutsk, Yakutia Autonomous Soviet Socialist Republic (ASSR). His mother Olga Biteniece (b. Reutova; 1936-2005) was born in the village of Kachug in the Irkutsk Region of Russia, and her parents were of the Cossack and Buryat descent. O. Biteniece worked at the post office in Yakutsk for several years, after moving to Latvia she was a warehouse manager at Liepāja Railway Station [1]. His father Debaldis Bitenieks (1935-2009) was born in Rucava Parish, Liepāja District. His parents were Margrieta Everte (1915-1997), a descendant of the Prussian family, and Mikelis Bitenieks (1897-1965), a Latvian who served in the Rucava Parish Board in the 1920s and 1930s [2] and in the Rucava Cooperative «Pašpalīdzība» [3], as well as in the credit union. In 1948, Mikelis Bitenieks was the Chairman of the Collective Farm «Vienība» [4]. M. Bitenieks was a Latvian rifleman, and in 1918, in an attempt to avoid the repressions of the German occupation power, he changed his native surname from Bite to Bitenieks. He was a respected man in the parish, probably for this reason the family was not affected by the Soviet repressions.

Valerijs' father D. Bitenieks worked in several professions: he was a driver, radio master, electrician, photographer, in 1989, he became one of the first individual farmers in the countryside, called Bresis farmers, (on 6 May 1989, the Supreme Council of the Latvian SSR passed the Law «On Farms in the Latvian SSR», which officially allowed establishment of individual farms in parallel with the Soviet collective farms. At that time, Vilnis Edvins Bresis was the Chairman of the Council of Ministers; therefore, those who established individual farms in accordance with the 
law were called Bresis farmers). D. Bitenieks served in the Soviet Army in Siberia, Yakutia ASSR, and met his future wife, Olga.

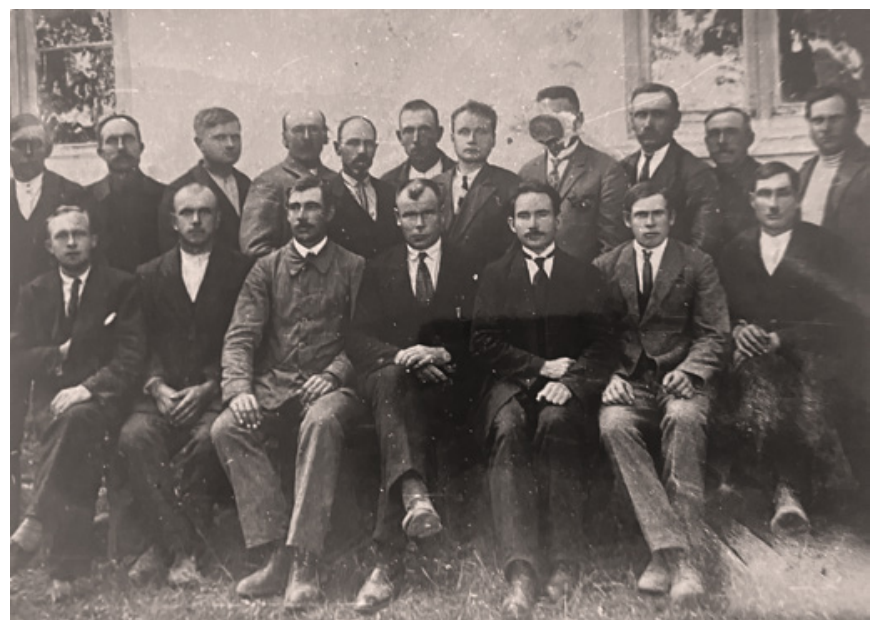

Figure 1. In the first row, the fourth from the left - Mikelis Bitenieks with the members of the Rucava Parish Board (in the early 1930s).

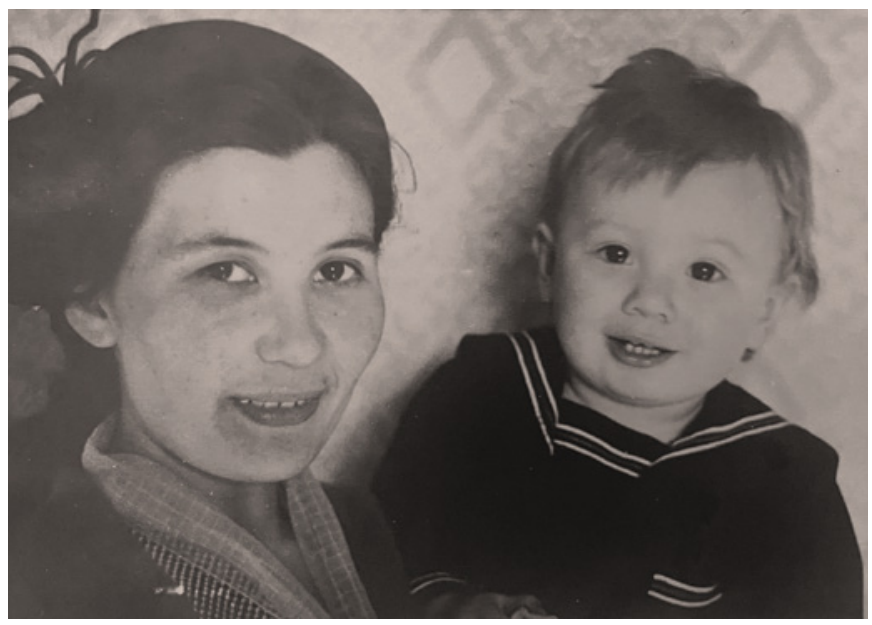

Figure 2.

Olga Biteniece with Valerijs in Rucava (c. 1961).

In the first interview with the author of the present article Érika Lanka, Valerijs Bitenieks remembered his parents' story about his birthday, «The day I was born was also my father's second birthday. That day he had to take a teacher with a pupil from the village to the city, it was about $200 \mathrm{~km}$ by taiga. The engine stalled on the road because snow had entered the tank. At the risk of freezing at $-40{ }^{\circ} \mathrm{C}$, he managed to start the engine and resume his journey. However, part of the fuel was spent to warm the passengers and warm up the engine, so they could not reach the city, and his father walked through the taiga for the remaining $20 \mathrm{~km}$ to get help in repairing the car» [5]. His wife had gone to the 
maternity hospital in Yakutsk that day to give birth to their son. When he returned, he found out that he had a son. All local Siberians had called Valerijs' father Valjera because they could not properly pronounce a difficult name Debaldis, so the son was also given this name (Valjera is an informal form of Valerijs). In RPI documents his name was written with a long vowel «ē» - Valērijs [6].

Figure 3. From left to right: father Debaldis, mother Olga with their younger son Vaironds in the lap and Valerijs in Liepāja (1976).

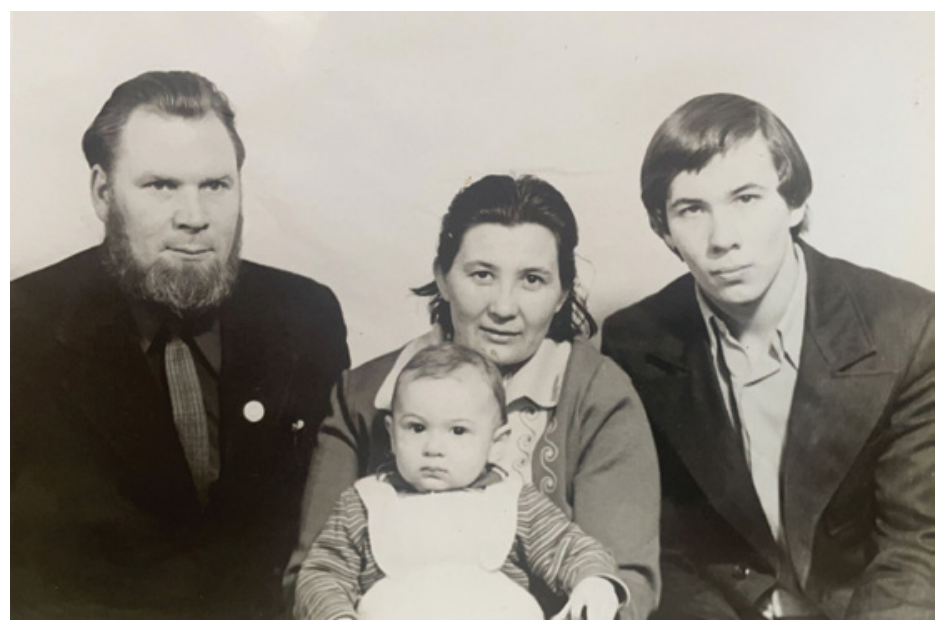

After the birth of their son, the family decided to return to Latvia. A long road to Rucava followed, where Valerijs stayed with his father's parents, while his parents got a job in Liepajja - the father became a radio master in Karosta (Military Port), repairing warship equipment; his mother became a manager of the railway warehouse. Only when his parents were given a room in the Karosta barracks, his parents took Valerijs from Rucava to Liepāja to live with them. The boy had already started to speak, and for some time he called his grandmother Margrieta his «first mother», and his mother - the "second mother». His parents were at work on weekdays, so Valerijs was often left with his grandmother because there were no vacancies in the kindergarten.

Just before Valerijs started school, in 1966, his father was given a two-room apartment in a so-called Khrushchev-era building, and Valerijs was given a place in the kindergarten, which he had attended for one year before some incident happened. The educator had locked him alone in one of the kindergarten rooms, the boy got angry and broke three windows with a broomstick. Until the 9th grade, Valerijs studied at Liepāja 11th Secondary School (1967-1975). Then V. Bitenieks, led by his father's dream and his desire to study at Leningrad (at present St. Petersburg) State University, passed the entrance exams and entered the mathematics class of Liepāja A. Pushkin Secondary School No. 2, 
which he graduated in 1977 [6] at the age of 17. Those who studied in Russian, at that time had to study at the secondary school for 10 years (10 grades), whereas those who studied in Latvian had to study for 11 years.
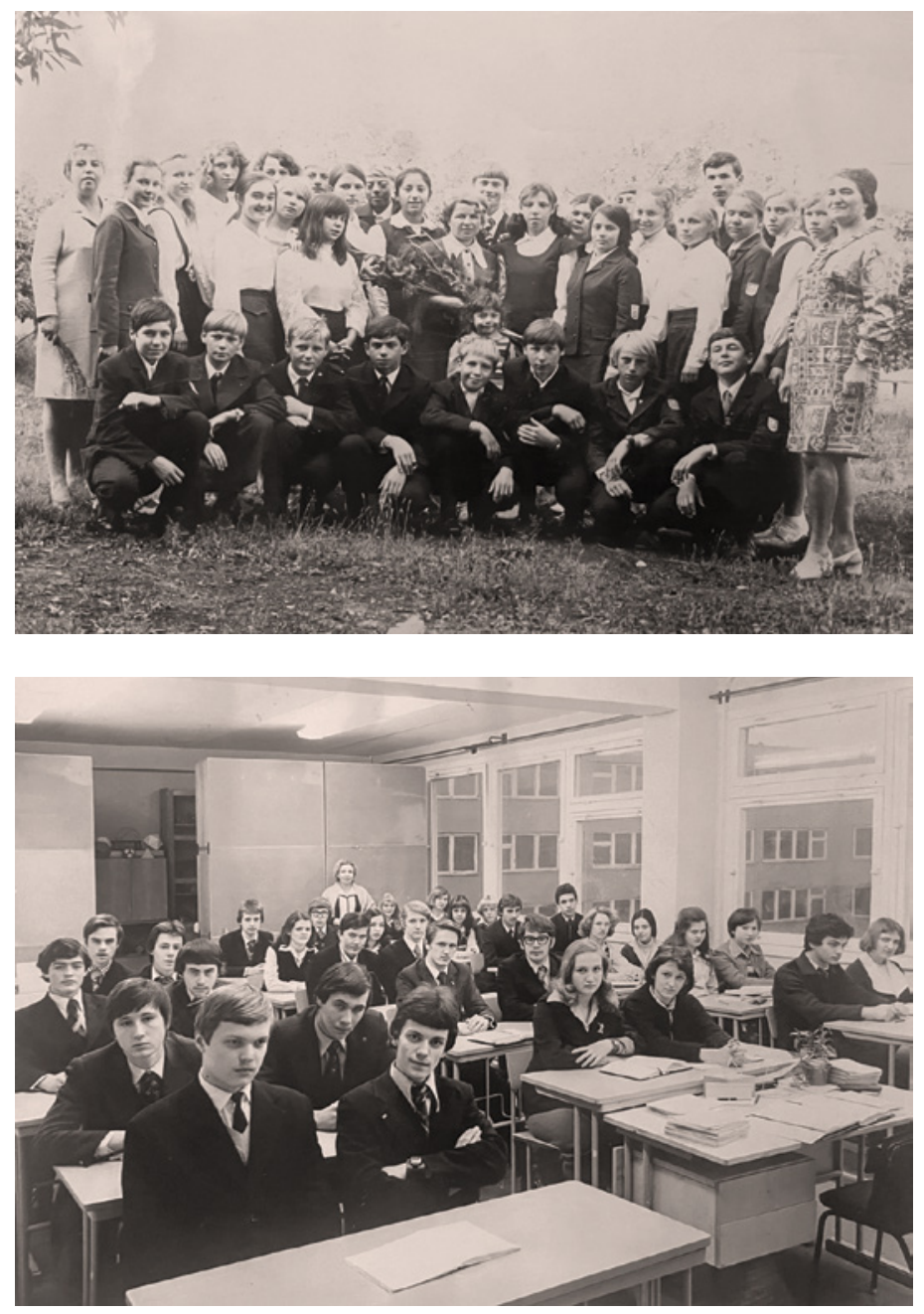

Figure 4. 8th grade at Liepāja 11th Secondary School.

$V$. Bitenieks - the tallest on the right of the third row.

Figure 5. 10th grade, mathematics class at Liepāja A. Pushkin Secondary School No. 2. V. Bitenieks - second in the second row from the left (1977).

In order to enter Leningrad State University, the average grade of a secondary school diploma had to be at least 4.8 (out of maximum 5), but Valerijs' grade was lower, so this dream could not come true. After secondary school, Valerijs started working at the Liepajja Factory «Liepājmaš», but after nine months he had to stop working. Upon reaching the age of 18 , young people, including $V$. Bitenieks, were drafted to the Soviet Army [6]. 


\section{Studies at RPI and the Beginning of the Career of a Civil Engineer}

From 5 May 1978 to 15 May 1980, V. Bitenieks [6] served at the Department of Communications on Duntes Street in Riga (where the regiment was located), but travelled to Bukulti when he was on duty. He also had to participate in the exercises, tracking the units of the NATO Armed Forces with the radio receivers - this, according to $V$. Bitenieks, was both dangerous and exciting [5].

Figure 6. Mother Olga with her sons Vaironds and Valerijs at the army conscription station on 7 May 1978.

Figure 7. From left to right: brothers Vaironds and Valerijs in Riga (1978).

Figure 8. From left to right: Valerijs Bitenieks and his brother Vaironds in Liepāja (1980).
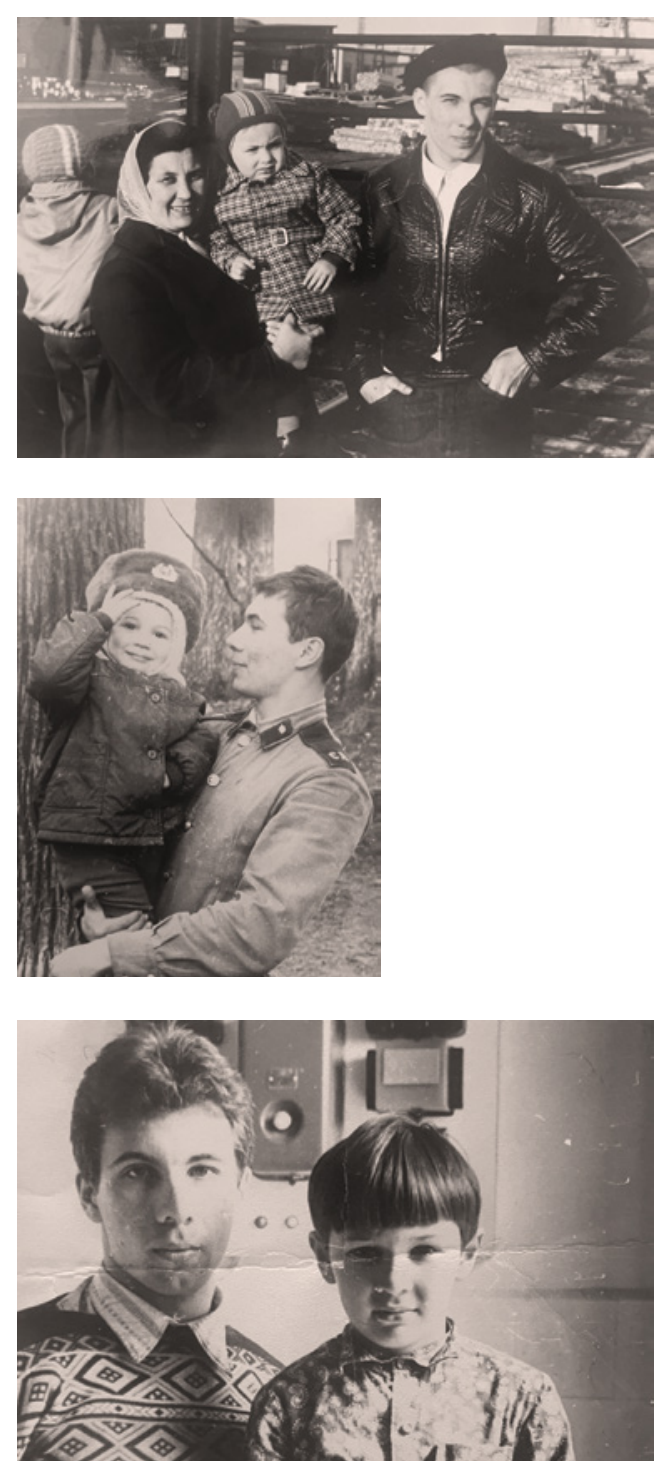
$V$. Bitenieks became interested in construction and decided to study at RPI after returning from the service in the Soviet Army, when in June 1980 he started working in a construction team as a concreter in Western Electrical Networks (WEN). He found this work with the help of his father, who was the WEN photographer at the time. Valerijs started to work in construction already in 1973, when he took part in the construction of a private house built by his father on the shore of Lake Liepāja on Tebras Street, performing various auxiliary works. He bought a bicycle for the money he earned [5].

In the autumn of 1980, V. Bitenieks entered the Evening Department of Industrial and Civil Construction Specialty of RPI Liepāja GeneralTechnical Evening and Extramural Faculty. While studying at the evening department, the workplace granted him an educational leave during the examination sessions. In the 1st study year, it lasted 20 calendar days [7; p. 113]. He received only excellent grades at the 1st year exams. V. Bitenieks worked and lived in Liepāja. In the autumn of 1981, V. Bitenieks moved to Riga and resumed his studies - this time as the 1st year student of the Day Department of RPI Faculty of Architecture and Civil Engineering. Valērijs received a WEN assignment to study at RPI Day Department, and he was awarded a company scholarship of 50 rubles. At that time, the students had to participate in a competition in order to be admitted to the university, but the applicants with workplace assignment, including $V$. Bitenieks, were exempted from the competition.

During his studies, the future engineer had undertaken three internships. During his internship in the 2nd study year, V. Bitenieks was supposed to participate in the refurbishment of the kindergarten. However, when he arrived to the place of internship, the foreman offered him to work on the construction of a multi-storey building. Valerijs accepted the offer and invited his fellow student Vitalijs Čmihovs, now a well-known Latvian entrepreneur. The students were paid on the accordbonus basis - a certain amount of money could be received for a certain piece of work in the specified time: every month three floors of a bricks nine-storey house had to be built. The students worked at a temperature of $+29^{\circ} \mathrm{C}$ from 8 am to $8 \mathrm{pm}$, and often had to deal with dizziness. There were also some accidents on the building site - once the crane operator caught on the newly bricked wall and it collapsed. But the plan was completed on time, and the students received a salary of 500 rubles. At that time, it was a lot of money, because an engineer's salary in those years was about 180 rubles per month.

After the 4th study year, $V$. Bitenieks underwent geodesy internship at the construction site of the Sigulda bobsleigh track, where the track supports had to be installed. At that time, in the lack of modern 
technologies, all marks had to be calculated with the help of the theodolite. It was not without curious incidents either. For example, a supervisor Ilmārs Brūmanis from Sigulda's mobile mechanized column followed and inspected the trainee's work, and once, taking the project drawing from the table, he looked at Valerijs' notes and critically noted that the foundation marks were calculated incorrectly - they needed to be made higher. The trainee objected and showed his calculations. The dispute continued until the manager noticed that he had the previous draft in his hands, which had been made before the amendments were made. Thus, the young student prevented a mistake in the construction of the track.

Figure 9. V. Bitenieks at the WEN construction site in Liepāja (1980).

Figure 10. V. Bitenieks during RPI geodesy internship in Sigulda (1985).
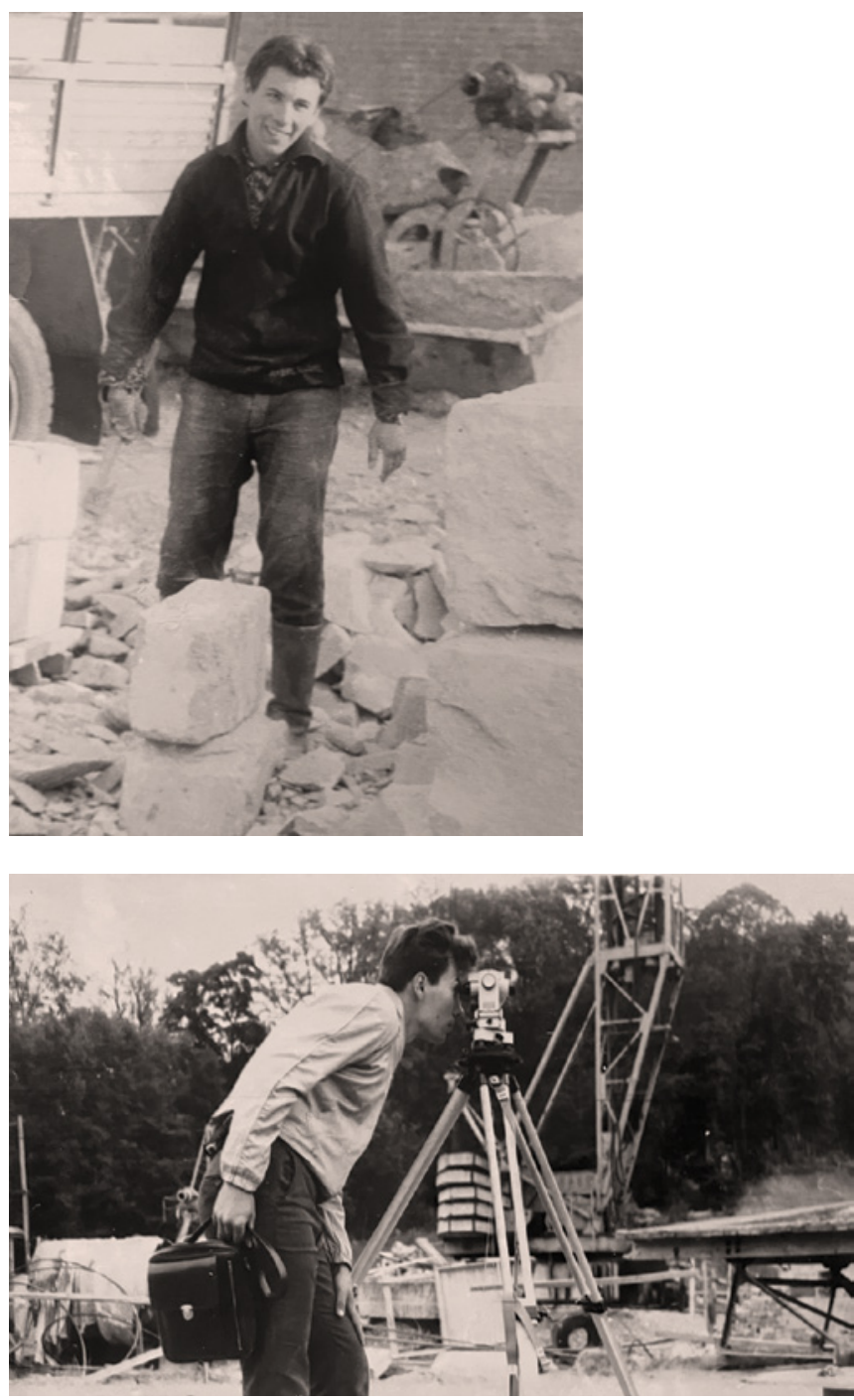


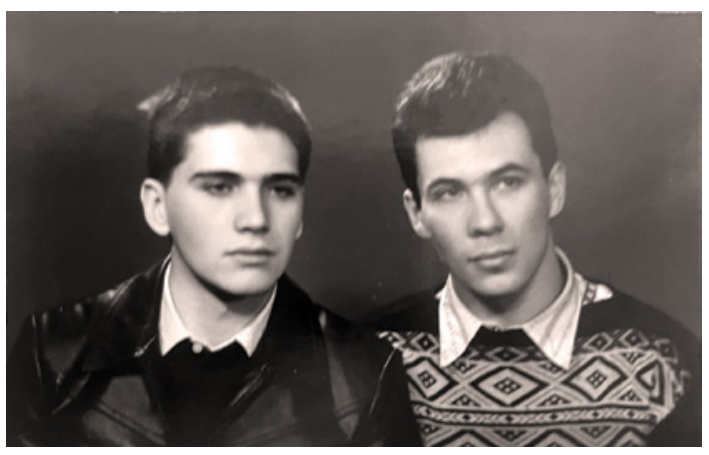

Figure 11. From left to right: RPI students Vitalijs Čmihovs and Valerijs Bitenieks, Riga (1982).

V. Bitenieks underwent the next internship in Tukums District, at the collective farm «Dzimtene». The task consisted in placing concrete in the foundations of the buildings. Valerijs was older than others and had experience in military service, so he was appointed a foreman. There were students from other groups in the brigade, many were late for work, and in order to interest them, $V$. Bitenieks invented a so called progressive pay option: payment increased with each subsequent working day. The last day of work was best paid, but only for those students who had worked for all previous days. As a result, those who had worked from the first day of the internship received a much higher salary.

Student life at RPI went its own way - studies ( $V$. Bitenieks still appreciates the thoroughness and usefulness of the knowledge he gained during his studies for his entire life and professional career), internships, examination sessions with tests, student life in the dormitories with discos in the free time.

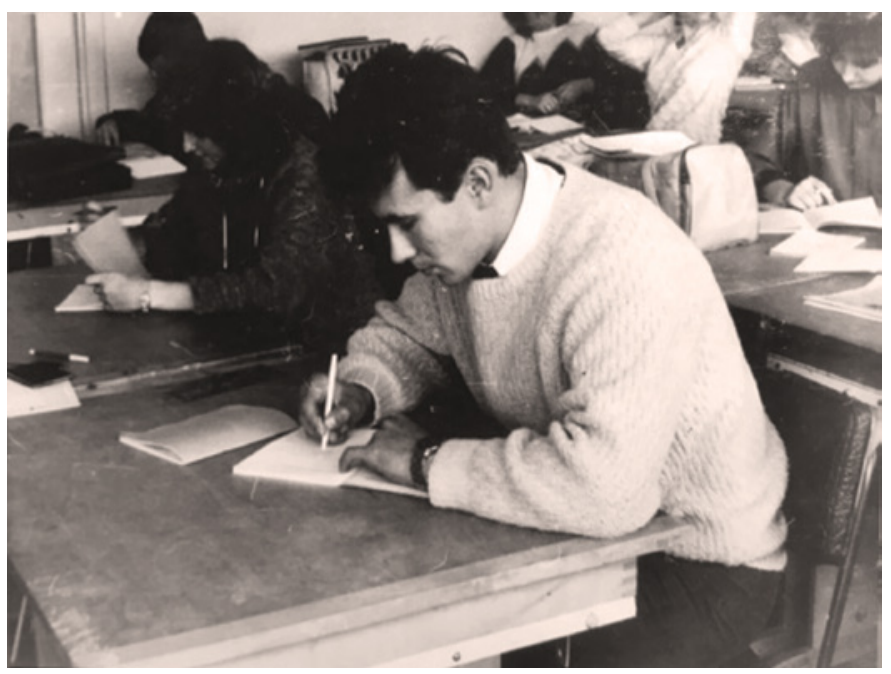

Figure 12. V. Bitenieks in the RPI auditorium in Kīpsala (c. 1983). 
Figure 13. From left to right: Valerijs Bitenieks, an unknown person and Vitālijs Kadišs at the RPI headquarters in Strēlnieku Square (1982).

Figure 14. RPI student dormitories at 4 Olaines Street in Ilǵuciems, Riga (c. 1982).

Figure 15. V. Bitenieks gathering potatoes (1981).

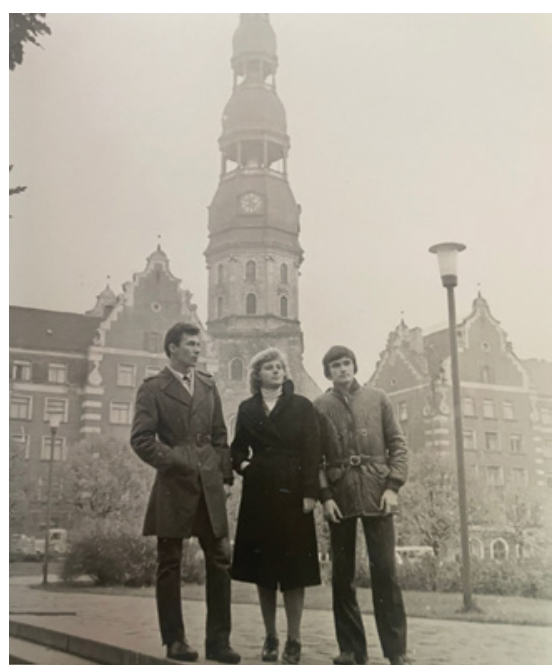

Valerijs Bitenieks from a Student of Riga Polytechnic Institute to a

\section{Construction}

Contractor in the

Independent Latvia
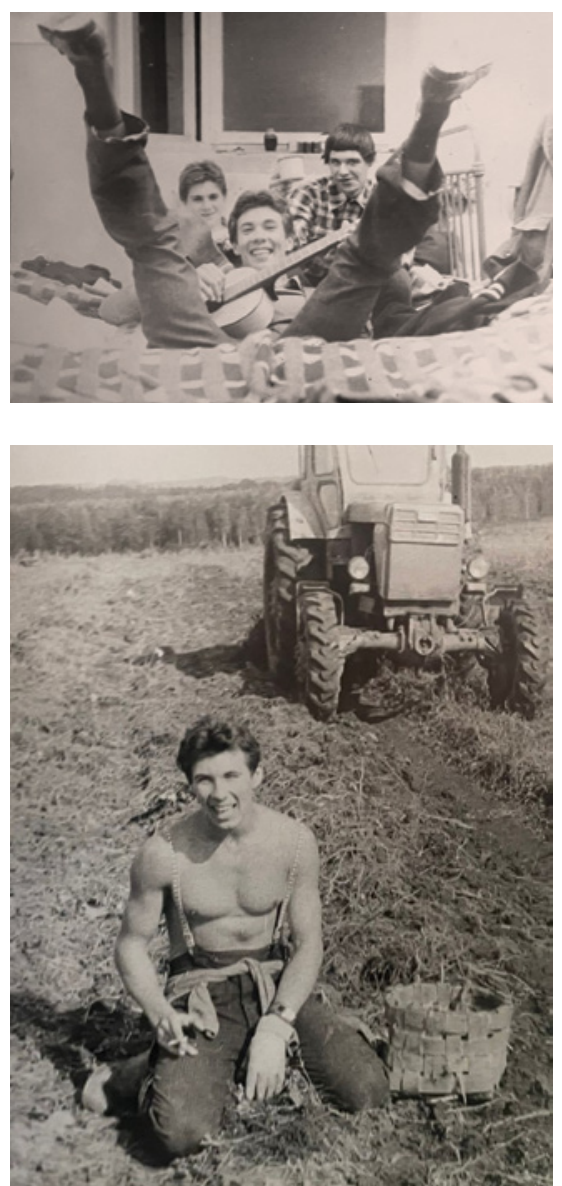
During the years of studies, in the 2nd study year, there was also one unpleasant incident. $V$. Bitenieks came to the practical class on the analysis of building materials with a considerable delay - only to the second part of the class. The dialogue with the lecturer was unpleasant. The student believed that he had an internship behind him and that he would do the practical work with honours, while the lecturer wanted the students to be disciplined. Following the lecturer's report, V. Bitenieks' behaviour was examined at the meeting of the Study-Education Committee of the Faculty of Architecture and Civil Engineering, and then also at the meeting of the Faculty Komsomol Office, because V. Bitenieks, like most students at the time, was a member of Komsomol (Young Communist League). He received a reprimand. At that time, student $V$. Bitenieks considered that attending $100 \%$ of classes alone would not guarantee good training of the specialists. Engineer $V$. Bitenieks still believes that students learn for themselves and each of them must critically evaluate what they know and can do, as well as use their time efficiently. At that time, probably both the student and the lecturer lacked the knowledge about efficient communication practices, because the matter could have been solved without the intervention of other people. Remembering his study years, $V$. Bitenieks in a conversation with RTU Professor Alida Zigmunde assessed the professionalism of RPI teaching staff and admitted that their main wish was to ensure the students develop understanding of the specific study subject. V. Bitenieks remembered the fact that he did not write a test in mathematics on time, so there was a discussion between the student and the lecturer. $V$. Bitenieks explained how he would solve the task and received a positive evaluation [8].

On 16 June 1986, V. Bitenieks received a diploma of an engineerbuilder in the field of industrial and civil construction [6]. At that time, RPI graduates were full of hope and confident about their future: the work was guaranteed by the so-called state allotment of the labour force - recent graduates were sent to specific companies, where they had to work for several years without the opportunity to resign. And no one even foresaw that the times of great change were approaching. Some of his groupmates went to work abroad, but Valerijs chose to stay in Latvia.

Students eligible for military service had to participate in the compulsory military training one day a week for the first four study years. Students took course exams in military subjects, spent 30 days in military camps in the army units, and passed the exam at the end of their studies [7; p. 96]. In summer of 1985, RPI students were sent to a military camp in Klooga, Estonia. This camp for reservist training («сборы») was also intended to strengthen the USSR armed forces with the qualified personnel. 
Figure 16. Diploma of an RPI graduate V. Bitenieks (1986).

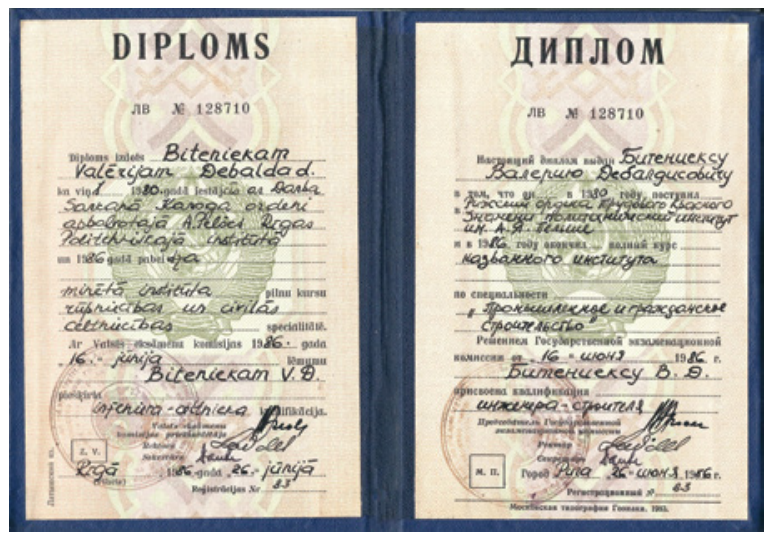

Valerijs Bitenieks from a Student of Riga Polytechnic Institute to a

Construction

Contractor in the Independent Latvia

Figure 17. Graduates of Group K3, RPI Industrial and Civil Construction Specialty. $V$. Bitenieks - the first from the right in the second row. Riga, on the stairs of the canteen at $\bar{A} z e n e s$ Street (1986).

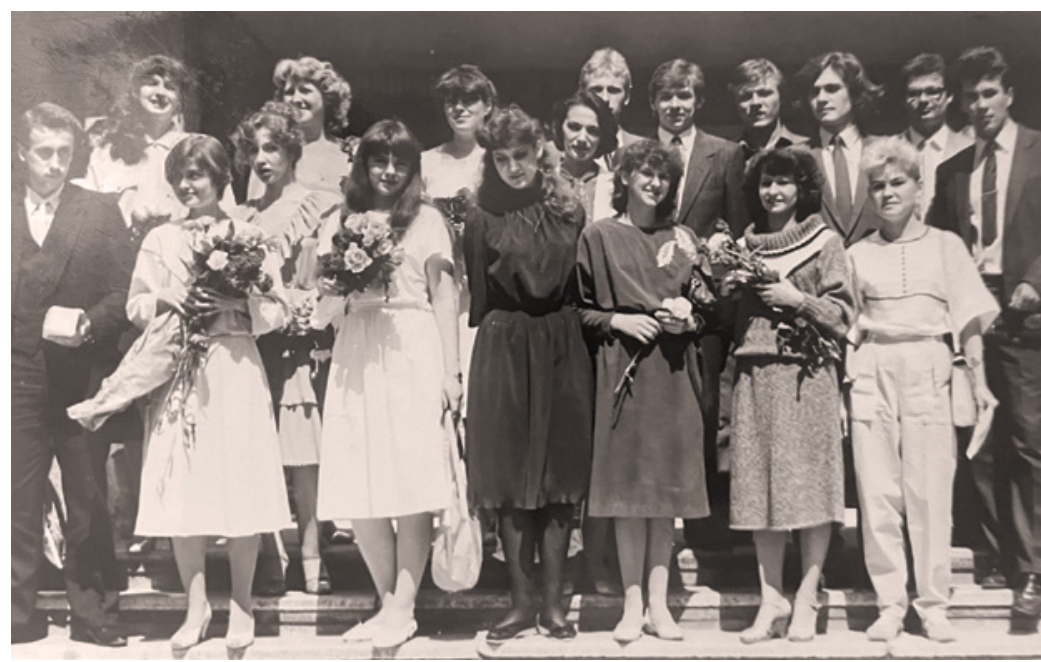

Figure 18. Junior Lieutenant $V$. Bitenieks after an examination at the military camp in Klooga (1985).

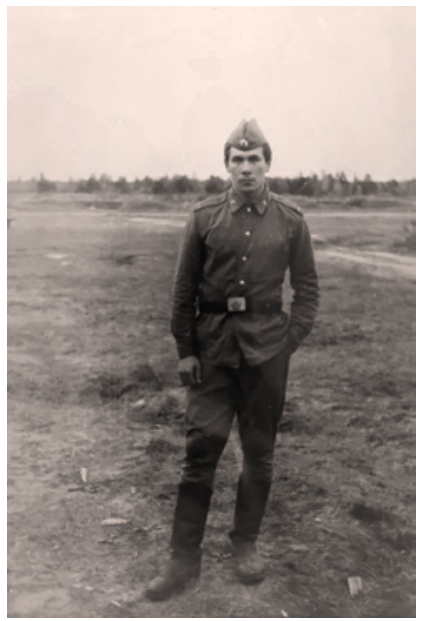




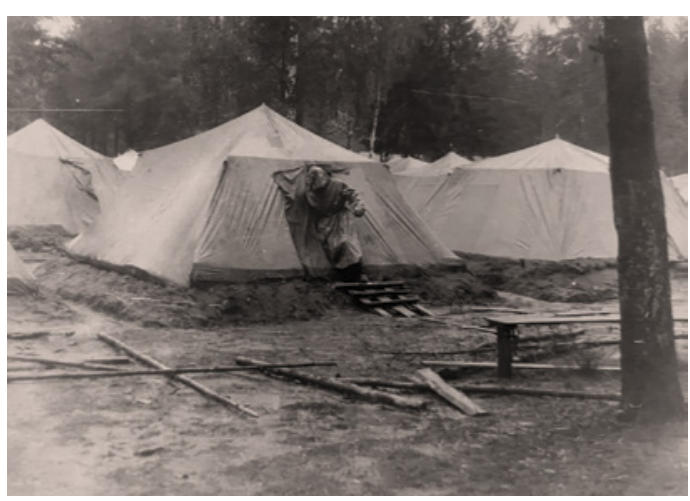

Figure 19. V. Bitenieks at RPI Student Military Camp in Klooga (1985).

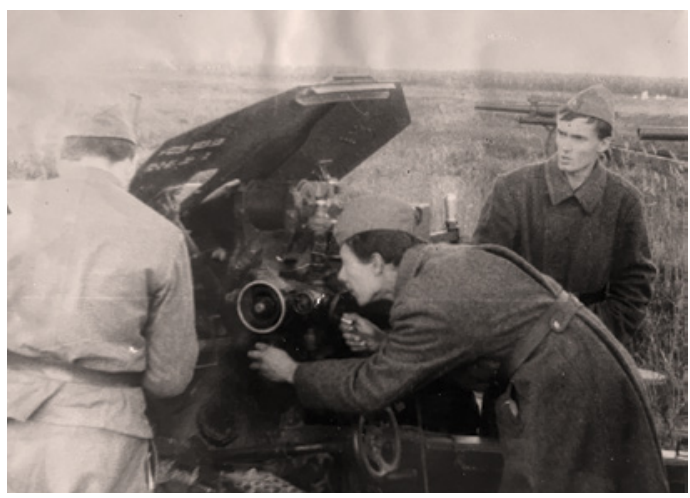

Figure 20. RPI students during the exam at the military camp in Klooga. From left to right: Valerijs Bitenieks and Vitālijs Kadišs (1985).

\section{Career Path, Family, and Economic Challenges}

After studies at RPI, V. Bitenieks as a holder of a company scholarship had to return to WEN Liepāja, which meant he had to live with his parents. Valerijs decided to start his independent life further away from home and asked for an assignment to the All-Union Komsomol Youth Construction Project - construction of Kansk Achinsk Thermal Power Plant Complex (KATPPC) in Siberia, which in the Soviet Union was frequently referred to as an «energy superpower» [9]. It was a huge complex uniting several lignite-fuelled power plants. At first, the young man was fascinated by the scale and scope of the construction, but after a year he was very disappointed, because the people who worked there were very different. After a couple of years, $V$. Bitenieks managed to get rid of the status of the new specialist and to move to the status of an «ordinary worker» and then - at his own will - quit the job.

Students of the 1980s, including V. Bitenieks, started families already during their studies. He went to Siberia with his family - his wife and daughter Linda [5]. In the interview with $\bar{E}$. Lanka, Valerijs repeatedly 
emphasized that his wife is a reliable and safe support of his life, his inspiration, partner, friend, wonderful mother and wife. In the first years of living together in Siberia, the young specialist Valerijs lived with his wife and daughter in a dormitory-type $12 \mathrm{~m}^{2}$ room. His wife got a job at a local library, she was a highly respected person in the region, and local newspapers even published articles about her. Unlike Valerijs, his wife enjoyed the job and was sorry to leave. However, the family expected their second child, so they decided to return to Latvia. In March 1988, the Bitenieks family arrived in Latvia, and in June they had their second daughter, Lelde. Valerijs started working at the Experimental Production Laboratory «Sigfarm» as a construction site engineer.

The return of the Bitenieks family from Siberia took place at an important time for Latvia - on 1 and 2 June 1988, the Plenary Session of the Creative Unions took place in Riga, and for the first time the desire to regain Latvia's status as an independent state was spelled clearly and loudly. In July, the founding congress of the political organization «Latvijas Nacionālās neatkarības kustība» (Latvian National Independence Movement) took place [10], V. Bitenieks and his colleagues joined the movement. After the congress, he handed over to the doctor and politician Jānis Straume his reserve officer's war certificate, which he received during his studies after training at the military camp in Klooga, Estonia. Later, V. Bitenieks together with $V$. Čmihovs participated in the events organized by the Latvian Awakening Socio-Political Movement and the work of the organization «Latvijas Tautas fronte» (Latvian People's Front). For example, he participated in the popular action «Baltijas celšs» (Baltic Way) on 23 August 1989, in January 1991, he went to the barricades, as well as together with his wife took part in the manifestation «Par neatkarigu Latviju» (For the Independent Latvia) on Daugavmala (the Daugava Harbour) on 18 November 1989. V. Bitenieks describes himself in the following way, «I am politically and nationally neutral myself - I do not join any party, and although I am a believer, I do not go to any church. I laugh that I am a Russian Latvian nationalist. And Buddhism is more appealing for me as a philosophy. I am also a pacifist [5].»

At the end of 1989, V. Bitenieks together with his friend, RPI graduate V. Čmihovs founded the cooperative «Bild». Vitālijs became the Chairman, while Valerijs started to supervise accounting matters. The cooperative worked under the auspices of the farm «Gauja», and the first object to be purchased was a sawmill. It was under repaired more than in operation, and there were no qualified specialists to run it. The founders had to take care about every task by themselves.

At the same time, V. Bitenieks' father - a Bresis farmer - managed to receive a large state loan for the construction of a cattle farm. The son 
was invited to the help as a certified builder. Valerijs had to say goodbye to the cooperative and to move in with his father to implement great plans. However, after the introduction of the Latvian ruble in 1992, all business plans had to be postponed and cancelled altogether later, because with the closure of the borders with the Russian Federation, all intentions to earn money in the eastern neighbour country had been put to an end. In the early 1990s, some new opportunities had to be considered, as it became possible to export goods to Europe. $V$. Bitenieks turned to timber harvesting, but it did not last long - timber prices in Latvia rose sharply only in the beginning, then, as competition increased, they decreased just as rapidly.

In 1995, V. Bitenieks returned to Sigulda because he realized that a construction engineer had to find another occupation. In search for work, he responded to an offer to run a small metal workshop that had been destroying in idleness. At that time, the popularity of heating stoves increased, and Valerijs' enterprising mind saw the opportunity, so he also turned to their manufacturing. But then some customer asked him to build a fireplace. At first, the businessman was concerned, but the customer was persistent, and Valerijs, who had previously built only one fireplace in his life - for himself, decided to try a new field of activity. It turned out great, and more and more orders for construction of new fireplaces were placed. However, there were many customers only in the autumn months, while there were no orders in winter and spring. The seasonal nature of work and irregular income already in the mid-1990s made $V$. Bitenieks realize that his average annual salary is lower than that of an auxiliary worker on a construction site [5]. And again, he had to consider changing the job.

Engineer $V$. Čmihovs offered $V$. Bitenieks to build him a house. The estimates were also made by Valerijs. Then Valerijs' fellow student decided that it would be better to invest money in the business - in the new wood drying kiln - and asked him for advice: whether it was more economical to custom build it or to buy a ready-made, prefabricated one. After the next estimate was made, $V$. Čmihovs and $V$. Bitenieks decided to build it themselves. V. Bitenieks started working for his friend V. Čmihovs, who opened his first sawmill in Gauja, near Sigulda, in 1990 [11]. Under his supervision, a fully operational sawmill gradually evolved from a half-ruined barn, where initially only four people worked [12]. Thanks to extensive timber exports and the contribution made by an investor from Germany, the old sawmill came back to life and began to bring profit. The enterprise turned from a cooperative into Ltd. «Gaujas Koks», and now it is one of the most profitable companies in Latvia. While building a wood drying kiln, Valerijs was appointed the construction manager for four workers who had previously worked at the sawmill. Although 
Valerijs did no really know anything about dryers, or fireplaces, he found books, read a lot in the evenings, and in the morning put new knowledge to life, because he likes the saying - «Those, who do not know what to fear, do not fear either». A large building with a boiler house, three dryers and office space on two floors was erected. However, due to some misunderstanding, $V$. Bitenieks left his job, started building fireplaces and considered the idea of founding his own company.

Figure 21. Valerijs Bitenieks during the creation of the panel production workshop (2002).

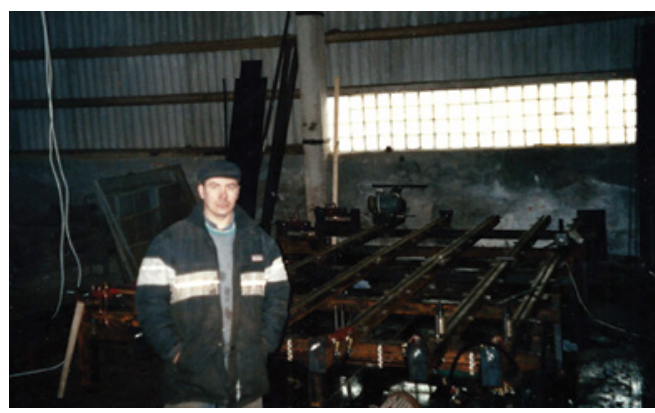

Figure 22. Construction of wooden panel house under the supervision of $V$. Bitenieks (2004).

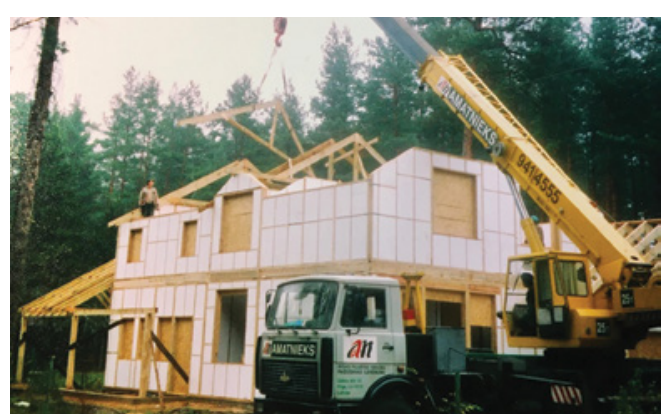

Figure 23. Fireplace designed by $V$. Bitenieks on Elizabetes Street in Riga (1996).

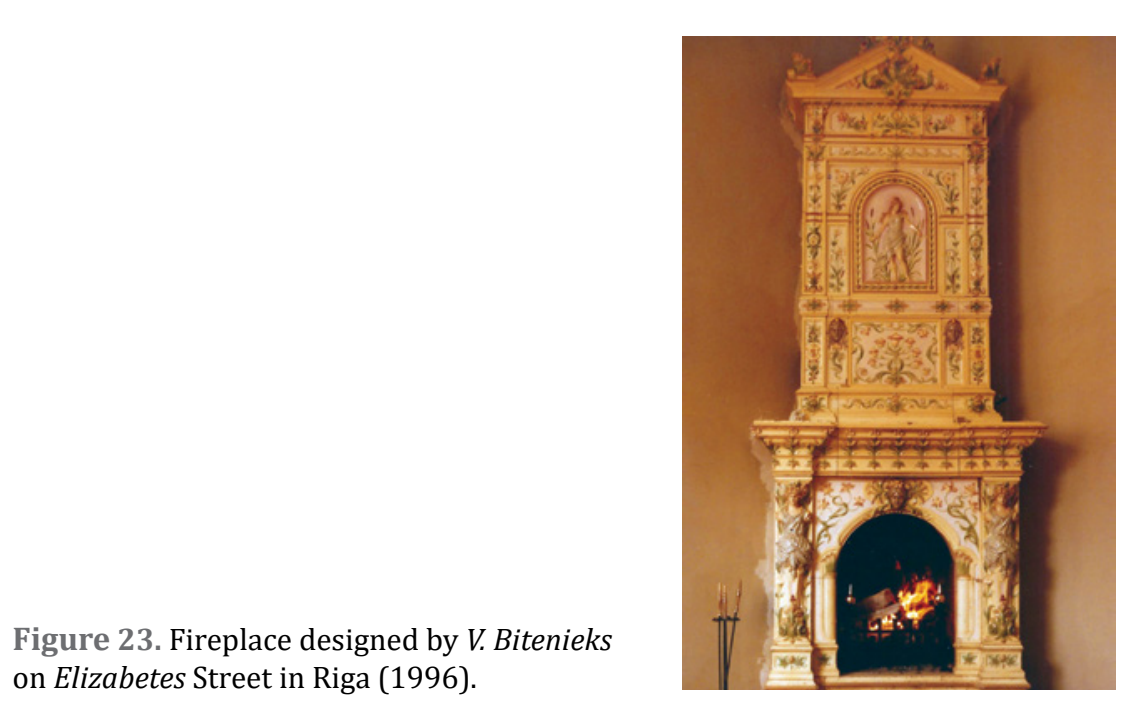

Valerijs Bitenieks from a Student of Riga Polytechnic Institute to a Construction Contractor in the Independent Latvia 


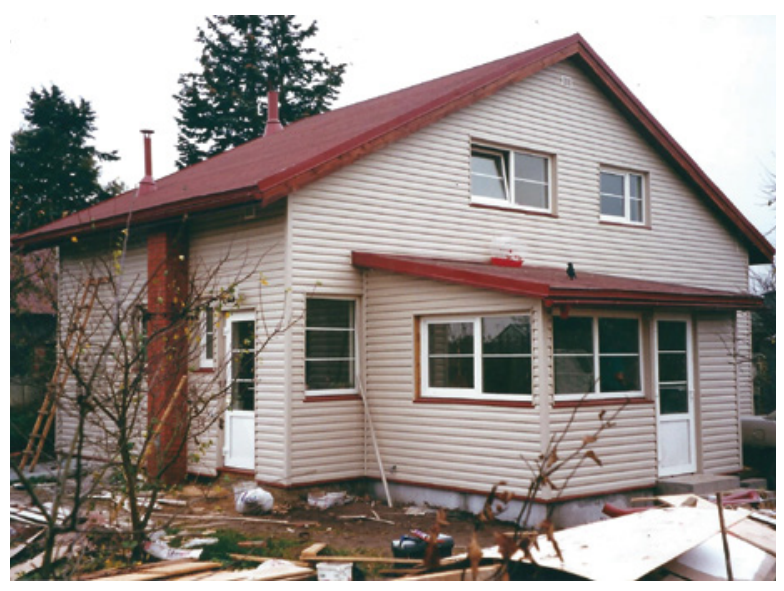

Figure 24. The house built by $V$. Bitenieks (from the foundations to the roof within two months) in August 2000.

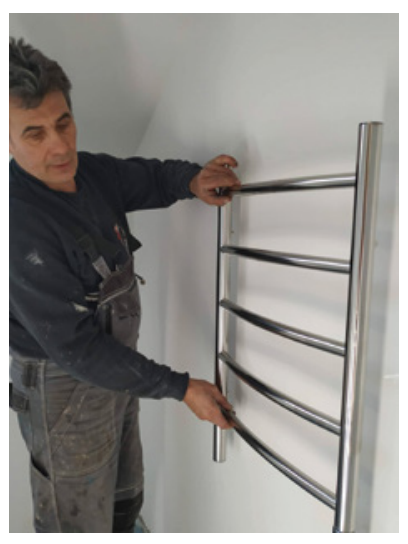

Figure 25. V. Bitenieks during improvement of a renovated house (2021).

Then a businessman and the owner of the hotel «Sigulda» Juris Dudko approached $V$. Bitenieks and offered him to build prefabricated wooden houses, which were made by the company «MJR» registered in Babite. After construction of a couple of houses, the next order followed - in a record time - in two months - to build a house from foundation to turnkey, transforming it from a garden house into a residential house. The builders handled it perfectly.

At the same time, $V$. Bitenieks concluded that he could build houses himself, the only thing he lacked as an investor. Only one investor showed interest, offering an investment of 3000 lats, but it was not enough even to purchase a good workbench. The experience of an entrepreneur, engineer and builder as well as this investment allowed $V$. Bitenieks to design a completely new machine, which had no analogues abroad. Using this machine, he started producing prefabricated panels that could later be assembled. Valerijs Bitenieks together with Edgars Vasilevskis received a Latvian patent for these panels in 2003 (LV 12971B 
«Sienas un pārseguma panel̦i mazstāvu ēku būvniecībai» (Wall and floor panels for the construction of low-rise buildings). About 15 houses were manufactured in two years. In the last year of operation, in 2005, during three months, four people at the workshop manufactured panels for the houses with the total floor area of about $1200 \mathrm{~m}^{2}$, and four more assembled them [5].

The entrepreneurial spirit made Valerijs Bitenieks look in a different direction - from panel houses to solid wood frame houses. He needed a partner, but could not find one. Realizing that he was left alone with his idea, the experienced builder $V$. Bitenieks joined a construction team working for Didzis Turausks, a businessman from Sigulda. V. Bitenieks worked for this company until 2008, when it went bankrupt, and again everything had to be started from scratch.

Since then, $V$. Bitenieks has been an individual entrepreneur who repairs and rebuilds houses, occasionally building fireplaces.

In 2022, Valerijs and his wife Ilmära will celebrate the 40th wedding anniversary, their two daughters - Linda and Lelde - and two grandsons - Austris and Ritvars make them happy and proud.

Figure 26. Valerijs and Ilmāra Bitenieks on their wedding day on 25 December 1982 in Sigulda.

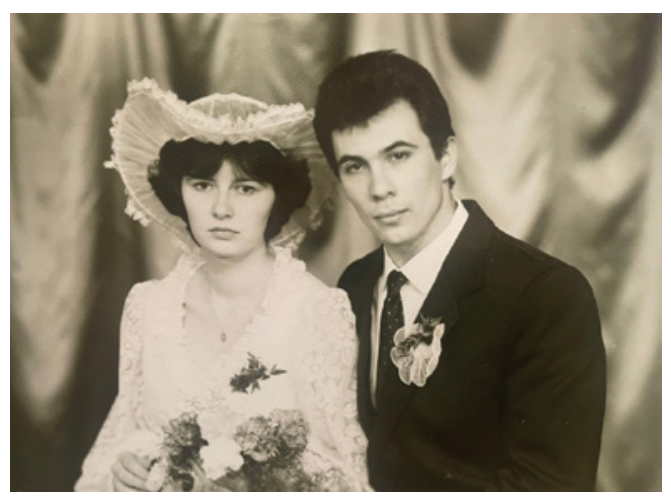

Figure 27. V. Bitenieks with his wife Ilmāra near Cêsis on the Baltic Way on 23 August 1989. Photo by V. Čmihovs.
Valerijs Bitenieks -

from a Student of Riga Polytechnic

Institute to a

Construction

Contractor in the

Independent Latvia 


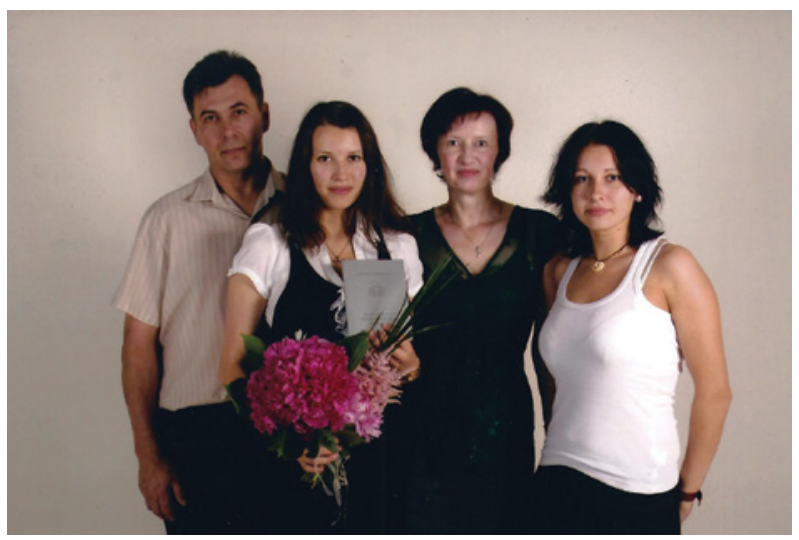

Figure 28. From left to right: $V$. Bitenieks, his daughter Lelde, his wife Ilmāra, and his daughter Linda, Riga (2010).

\section{Conclusions}

An RPI graduate $V$. Bitenieks was born and raised during the Soviet rule in the second half of the 20th century and was one of those who always tried to get ahead of time and define further goals. He was a typical Soviet student, he achieved his dream to gain a university degree and the qualification of an engineer. As a professional, he has tried to bear the name of a civil engineer with honour both during the Soviet rule and in the restored Republic of Latvia. V. Bitenieks belongs to the cohort of RPI graduates who dedicate their entire lives to the acquired profession, always keep up with the times, and as enterprising professionals are ahead of their time with their ideas, being proud of their profession. V. Bitenieks' professional activity and achievements, including human qualities and self-esteem, have always made a great contribution to Latvia and its construction industry. Although more than a half of the members of his study group live and work abroad, $V$. Bitenieks is and will remain a Latvian patriot, who uses his knowledge acquired at the university in the homeland of his ancestors. In his work, $V$. Bitenieks employs important character traits and life values, which he acquired from his parents and their ancestors - a sense of duty from his father, pedantry from a Prussian grandmother, an understanding of honour and sincerity from his Cossack grandparents, strategic thinking from his grandfather - Rucava Parish elder, interest in Reiki healing and Buddhism from his Buryat grandmother.

He can be a role model for those RTU students who are now studying civil engineering. 


\section{REFERENCES}

[1] Olgas Bitenieces personas dokumenti. Valerija Bitenieka personīgais arhīvs.

[2] Rucavas pagasta vēlēšanu dokumenti. Latvijas Nacionālā arhīva Latvijas Valsts vēstures arhīvs 4507. f., 1. apr., 6. l., 225. lp.

[3] Rucavas kooperatīva «Pašpalīdzība» pārskats par 1932. gadu. Kopdarbība, Nr. 6., 1933. gada 25. februārī, 6. lpp.

[4] Salmiṇš, G.,., Timbra, G. Ar Rucavas vārdu - lapu pa lapai: ieskats Rucavas vēsturē. Rucava: Rucavas novada dome, 2020, 244., 423. lpp.

[5] Ērikas Lankas intervija ar Valeriju Bitenieku 2020. gada 11. decembrī. $\bar{E}$. Lankas personīgais arhīvs.

[6] RPI studenta V. Bitenieka personāllieta. RPI/RTU arhīvs.

[7] Augstākās tehniskās izglītības vēsture Latvijā. 3. daḷa. Rīga: RTU, 2007, 96., 113. lpp.

[8] Alīdas Zigmundes intervija ar Valeriju Bitenieku 2021. gada 10. jūnijā. A. Zigmundes personīgais arhīvs.

[9] Beḷavniece, V. ...Caurā akā ūdens nestāv. Padomju Jaunatne, 1987. gada 15. aprīlis, Nr. 74, 2. lpp.

[10] Mednis, I. Partiju laiki Latvijā (1988-2002). Rīga: Drukātava, 2007, 75. lpp.

[11] Būvinženieri Latvijai. Rīga: Latvijas Būvinženieru savienība, 2002, 21. lpp.

[12] TOP 10: Latvijas biznesa veterāni, kuri tirgū noturējušies vismaz 25 gadus Top2: Vitālijs Cmihovs «Gaujas koks» (100 \%). 17.11.2018 [tiešsaiste]. https://www.delfi.lv/bizness/biznesa_vide/top-10latvijas-biznesa-veterani-kuri-tirgu-noturejusies-vismaz-25gadus.d?id=50580923\&page $=9$ [skatīts: 10.01 .2021 ] .
Valerijs Bitenieks -

from a Student of

Riga Polytechnic

Institute to a

Construction

Contractor in the

Independent Latvia

\section{SOURCES OF ILLUSTRATIONS}

Figure 1-28. Valerija Bitenieka personīgais arhīvs. 


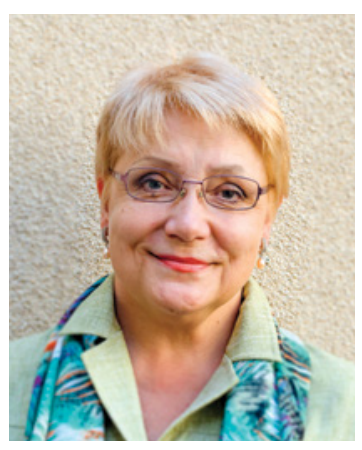

ĒRIKA LANKA, Mg. paed., Mg. phil., graduated from the University of Latvia. From 1984, she is a Lecturer at the Faculty of Education (FE) of the University of Latvia. From 2008 onwards she has worked as the Director of one of the Programmes at the Adult Pedagogical Education Centre (APEC) of the Faculty of Education, Psychology and Art. She participated as an expert in a lot of research projects in Latvia and abroad, at the same time she worked as a teacher at schools. Her main academic interests include the philosophy of education, ethics, axiology, values and codex of the teacher, history of pedagogy in Latvia and in Europe. She is the co-author of two monographies and the author of more than 42 publications.

Address: Imantas 7. linnija, 1, Rìga, LV 1083, Latvia

Phone: +37129264829

E-mail: erika.lanka@lu.lv,erikalanka@inbox.lv

Érika Lanka

\section{Valerijs Bitenieks - no Rīgas Politehniskā institūta studenta līdz būvuzṇēmējam neatkarīgajā Latvijā}

Pētījums par Rīgas Politehniskā institūta (RPI) Arhitektūras un celtniecības fakultātes absolventu (1986) Valeriju Bitenieku atklāj padomju studentu ikdienu 20. gadsimta 80. gados, jaunā inženiera darbību, izmēǵinot dažādas iespējas darba tirgū un inženiera izaugsmi par veiksmīgu būvuzṇēmēju neatkarīgajā Latvijā 21. gadsimtā. Tajā izsekots V. Bitenieka dzīvei no bērnības līdz mūsdienām, pievēršot uzmanību viṇa profesionālajai darbībai. Veicot pētījumu, gūts ieskats par studentu prakses un ārpusstudiju aktivitātēm padomju laikā, iegūti nepublicēti un plašākai sabiedrībai nezināmi fotomateriāli.

Atslēgas vārdi: Valerijs Bitenieks, Rīgas Politehniskais institūts, būvuzñēmējdarbība. 